\title{
FOKUS PADA KEPUASAN PELANGGAN
}

\author{
Muhammad Abrori
}

Email : muhammadabrory09@gmail.com

\begin{abstract}
ABSTRAK
Terpadu nyamutu menejemen yang diterjemahkan dari ejumlah kesluruhan Qualitas Managemen (TQM) atau disebut juga Pengelolaannya Mutu Total atau PMT yaitu suatu pendekatan taraf pendidikan melalui peningkatan derajat keseluruhan tersebut. Hanafiah jusuf, dkk.

Mendefinisikan Pengelolaan taraf Total (PMT) merupakan salah satu pendekatan yang teratur, mudah, dan strategi dalam penyelenggaraan di sebuah organisasi, yang memprioritaskan pada kepentingan konsumen. Pendekatan ini dilakukan dangen maksut bertujuan meningkatkan serta mengendalikan kualitas. Adapun yang dimaksud dengan Pengelolaan Mutu jumlah atau PMT pendidikan yan tinggi atau juga bisa sekolah) dalam melakukan mengelola lembaga pendidikan tersebut harus didasari oleh filosofi yang mana untuk meningkatkan kualitas perlu diadakan dan dilaksanakan oleh semua lembaga sejak dulu secara terpadu dan berkelanjutan hingga pendidikan bisa sebagai jasa yang berupa kegiatan berkelanjutan atau proses kebudayaan sesuai dengan kebutuhan para pelanggan baik sekarang ataupun yang akan datang.
\end{abstract}

Kata Kunci: definisi pelanggan, identifikasi jenis pelanggan

\section{Pendahuluan}

Berbagai usaha telah, sedang dan masih akan dilakukan untuk meningkatkan kualitas 
suatu pendidikan yang dilaksanakan secara bertahap dan berkelanjutan. Strategi yang dilakukan pun berjalan dengan mengikuti alur kehidupan yang semakin modern, lebih efektif dan efesien.

Usaha yang dilakukan bermaksud untuk meningkatkan kualitas berkelanjutan dimasa mendatang yang dikenal dengan jumal keseluruhan Quality Management (TQM). Tidak semua instansi menggunakan kata TQM didalamnya, beberapa organisasi menggunakan nama yang telah disepakati oleh kelompok, contohnya Total Quality Control, Total Quality Servise, Continius Improvement, Strategi Quality Initiateves, ataupun Sistem Manajemen mutu.

Dengan penamaan yang dipilih oleh kelompok memiliki satu tujuan, yaitu berpengaruh terhadap budaya kualitas didalam organisasi tersebut. Manajemen Mutu Terapdu sangat pouler di berbagai lingkungan organisasi profite, khususnya pada suatu lingkungan berbagai macam badan institusi usaha atau perusahaan dan industry, yang telah terbukti akan keberhasilannya dari masing-masing di dalam kondisi bisnis yakometitif._

Kondisi seerti ini telah mendorong berbagai pihak untuk memraktikannya di lingkungan organisasi nonprofit termasuk di lingkungan institusi. Menurut Bounds, seerti yang dikutip oleh mulyadi mengatakan bahwa manajemen mutu teradu atau dikenal dengan TQM adalah suatu sistem manajemen yang berfokus keada orang yang bertujuan untukmeningkatkan secara terus menerus kepuasannya customere pada biaya sesungguhnya yang pasti berkelanjutan terus menurun._

Lebih lanjut, mulyadi mengemukakan bahwa TQM atau total quality menejemen merupakan pendekatan pendekatan dengan sistem secara menyeluruh (bukan suatu bidang atau program terpisah) dan meruakan bagian dari teradu strategi tingkat tinggi. Sistem ini bekerja cepat dan tidak staknan secara horizontal yang menembus fungsi dan daertemen, melibatkan semua karyawan dari atas samai bawah, meluas dari hulu dan ke hilir, mencakup mata rantai pemasok dan customer._

Menurut Nawari hadari, Manajemen Mutu Terpadu atau MMT adalah manajemen fungsionalisme dengan pendekatan yang hal itu secara terus menerus selalu terfokuskan kepada peningkatan kuality, agar produk produk yang di keluarkan sesuai atau selaras dengan standar kualitas dari masyarakat itu sendiri yang dilayani dalam tugas pelayanan yang umum 
atau public service, dan pembangunan dalam masyarakat (communitas develoment)._

Konsepnya didasarkan pada manajemen sebagai rangkaian kegiatan menintegrasikan sumber daya yang mereka miliki, yang harus kita integrasi pula dengan tujuan atau tahapan pelaksanaan fungsi-fungsi manajemen, agar terwujudnya kerja sebagai aktivitas produksi berkualitas. Setiap anggota kinerja dalam manajemen mutu atau MMT terpadu yang harus dilakukan melalui tahaan perencanaan, persiaan, pelaksanaan teknis dengan metode kerja yang berguna dan tepat, untuk menghasilkan produk produk yang selalu bermanfaat bagi setiap masyarakat luas.

Pengertian lain dikemukakan oleh santoso yang dikuti oleh fandi Tjiptono dan Anastasia Diana yang mangatakan bahwa: "TQM meruakan system sisytem manajemen yang mengangkat kualitas sebagai strategi usaha dan berorentasi ada kepuasan pelanggan dengan melibatkan keseluruhan anggota organisasinya."_ Di saming itu, fandy Tjipto dan anastasia Diana menyatakan pula bahwa Total Quality Management ialah sebuah cara untuk melaksanakan usaha yang mencoba untuk memaksimalkan persaingan organisasi melalui perbaikan berkelanjutan atas produk, karyawan, proses, dan lingkungannya._

Dalam ajaran Total Quality Management (TQM), suatu lembaga pendidikan atau sekolah harus menempatkan seluruh siswa sebagai "klaien" atau dalam istilah erusahaan sebagai "stakeholders" yang tersebar, maka suarasuara siswa harus di sertakan dalam setia pengambilan keputusanharus dengan cara strategis langkah organisasi yang ada di sekolah. Tanpa keadaan yang demokratisitas manajemen itu tidak bisa menerapkan Total Quality Management (TQM), yang terjadi adalah kualitas dalam naungan pendidikan didominasi oleh berpihak tertentunya yang sering kali memiliki kepentingan keentingan yang berlawanan dengan hakikat pendidikan. Peneraan TQM berarti juga adanya mempunyai kebebasan untuk berpendapat atau berargumen.

Kebebasan tersebut akan menciptakan sebuah iklim yang dialogis antara siswa dan guru, antara siswa dan keala sekolah, antara guru dan keala sekolah, singkatnya adalah kebebasan berpendaat dan keterbukaan antara warga sekolah. Pentransferan ilmu engetahuan tidaklagi bersifat one way communication, melainkan two way communication. Proses dua arah ini merupakan bagian dari substansionalisme in Total Quality Management atau TQM dalam meningkatkan kualitas dankuantitas di suatu lembaga pendidikan. 
Sehingga di lingkungan organisasi nonprofit, khususnya pendidikan, penetapan mutu produk dan kualitas harus memunyai suatu proses untuk mewujudkannya, merupakan bagian yang tidak mudah didalam pengimlementasian Manajemen Mutu Teradu (TQM). Kesulitan ini dikarenakan oleh ukuran produktivitasnya hanya hanya bersifat kuantitatif, misalnya hanyadari jumlah lokal area dan gedung institusi atau laboratoriume yang berhasil dibangun, akan tetapi juga berkenaan dengan aspek kualitasnya menyangkut dengan kemanfaatan dan kemampuaan memanfaatkannya.

\section{Definisi Pelanggan}

Pelanggan yaitu semua orang yang sering menuntut kita/Institusi untuk memenuhi standar kualitas tertentu yang di inginkan oleh pelanggan, oleh karena itu pelanggan akan memberikan sanagat memberi pengaruh pada performa kita atau perusahaan yang kita jalankan Dan berikut definisi tentang pelanggan, diantaranya: Pelanggan orang yang tidak bergantung kepada kita, akan tetapi kita yang bergantung kepadanya. Pelanggan adalah orang orang yang membawa kita terhadap keinginannya.

Tidak ada seorangpun yang pernah menang beradu pendapat atau argumen kepada seorang pelanggan. Konsumen adalah orang yang sangat penting yang tidak bisa dihapuskan dalam sebuah lembaga/institusi. Dari beberapa definisi pelangganatau konsumen di atas, bisa disimpulkan bahwasannya suatu palanggan adalah orang yang menggunakan jasa kita dalam memenuhi permintaan atau kebutuhannya, dan kita membutuhkan mereka mereka untuk yang dapat menjalankan perusahaan atau badan lembaga yang kita kelola.

\section{Identifikasi Jenis Pelanggan}

Dalam memberikan kepuasan untuk pelanggan lebih baiknya diidentifikasi macammacam pelanggan. Ada 2 jenis pelanggan dalam sistem kualitas modern, yaitu: Pelanggan Internal diantaranya: guru, pustakawan, laboran, teknisi, dan tenaga administrasi. Pelanggan Eksternal terdiri atas: pelanggan primer (murid), pelanggan yang sekunder atau orang tua, pemerintah, dan masyarakat), pelanggan tersier (pengguna/penerima lulusan baik di perguruan tinggi maupun dunia usaha).

Sehingga pada tataran ini sekolah dalam me-manage pola organisasi dalam meningkatkan kuaitas mutu pendidikan minimal ada 7 prinsip yang harus diterapkan dalam 
tataran praksis manajerial sekolah, yaitu:

\section{Fokus Pada Pelanggan}

Organisasi bergantung pada pelanggan, oleh karena itu organisasi seharusnya memahami kebutuhan pelanggan masa sekarang dan masa yang akan mendatang, juga harus memenuhi persyaratan dan berusaha melampaui dengan harapan pelanggan.

Kemampuan menarik perhatian, melayani dan memelihara pelanggan adalah tujuan yang sangat tinggi dari institusilsekolah. Tanpa terlalu fokus dan keterlibatan pelanggan, tujuan manajemen mutu yang sesungguhnya tidak berarti. Organisasi yang berfokuskan kepada orientasi pelayanan sebagai perangkat utama atau juga dalam melaksanakan misinya.

Adapun dalam lingkup pendidikan kepuasan pengguna jasa dalam sebuah pendidikan merupakan factor faktor yang benar-benar penting dalam Total Quality Managemen(TQM). Oleh karena itu, identifikasi penggunaan jasa pendidikan dan kebutuhan mereka merupakan sebuah aspek yang pasti krusial. Adapun langkah awal Total Quality Management atau TQM adalah memandang peserta didik sebagai pelanggan yang harus dilayani dengan sebai baiknya.

\section{Kepemiminan}

Pemimpin menetapkan kesatuan yang bertujuan tujuan dan arah organisasi. Pemimin uncak menyusun visi dan misi sekolahnya dengan benar dan jelas dan dilengkai dengan sasaran atau tujuan yang harus konsisten dan didukung pula dengan perencanaan taktis dan strategis.

Oleh sebab itu, kesadaran akan mutu dalam suatu lembaga pendidikan yang tergantung pada faktor intangible, terutama sikap manajemen tingkat yang paling teratas atau pimpinan lembaga pendidikan dasar menengah atau keatas sekolah) terhadap kualitas lembaga pendidikan. Pencapaian tingkat bermutu atau berkualitas bukan hasil penerapan jangka pendek atau jangka npanjang untuk menetapkan daya saing, melainkan melalui imlementasi TQM yang mensyaratkan keemimpinan yang kontinu._ Dewan sekolah, pengawas, dan administrator berperan didalam memfokuskan dan memberikan arahan kepada wilayah dan sekolah.

Merekalah yang memiliki visi misi kedepannya, dan mereka jugalah yang harus berkemampuan mengajak para guru dan staf dari berbagai kelayen untuk mau menerima visi 
dan misi itu sebagai pemiliknya. Ini mengacu kepada berbagai tanggung jawab bersama para guru dan staf staf yang memiliki komitmen untuk mewujudkan visi dan misi tersebut. Pemimpin itu diperlukan memiliki karakteristikal pribadi yang mencakup dorongan, motivasi untuk pemimpin, kejujuran dan integritaas, keercayaan diri, inisiatif, kreativitas/originalitas, adaptabilitas/fleksibilitas, kemampuan kognitif, serta pengetahuan dan kharisma.

Kualitas manajerial pimpinanitu diharuskan dapat memberikan inspirasi kepada semua jajaran manajemennya agar mampu untuk mengembangkan suatu budaya TQM. Oleh karena itu, keterlibatan yang langsung pemimpin lembaga pendidikan sangatlah pentinng.

\section{Pelibatan Anggota}

kepada semua tingkatan merupakan inti suatu organisasi, dan pelibatan penuh mereka semua memungkinkan kemampuannya harus dipakai untuk manfaat organisasiyanya. Para karyawan harus dilibatkan kepada seluruh proses prosses untuk menyusun arah dan tujuan serta peralatan yang diperlukan untuk mencapai tujuan kuality mutu, sehingga setiap individu akan terlibet dan punya tanggung jawab yang besar untuk mencari perbaikan yang terusmenerus terhadap proses proses yang berada pada lingkungan tugasnya tersebut. Memperbaiki proses kerja kita hanyalah akan berhasil jika semua pihak, dari atas sampai ke proses bawa ataupun juga persilangan antarfungsi tersebut, terlibat dalam perubahan.

\section{Pendekatan Proses}

Pendekatan proses adalah suatu pendekatan untuk perencanaan,pengendalian, juga peningkatan dalam proses-proses utama dalam sebuah sekolah atau trilogi proses mutu denghan menekankan pada kemauan pelanggan daripada kemauan fungsional. Orientasi proses ini membutuhkan perubahan yang cukup signifikan, dikarenakan banyaknya manajemen yang lebih berorinentasi pada produk dari pada hanay suatu proses.

\section{Pendekatan Sistem}

pada Manajemen Sistem didefinisikan sebagai sekumpulan dari belbagai bagian/komponen yang satu dengan yang lain saling berhubungan dan saling membutuhkan untuk mencapai tujuan. Pendekatan sistem melihat suatu organisasi secara universal daripada bagian, yang diekspresikan sebagai holistik. Perbaikan Berhubungan dengan Perbaikan yang berkesinambungan atas kinerja organisasi organisasi secara menyeluruh hendaknya di jadikan sbagai sasaran teta dari organisasi.

\section{Proses berkesinambungan}

Proses berkesinambungan adalah prinsip dasar di mana mutu menjadi pusatnya roses 
ini merupakan pelengkap dan yang menghidukan prinsip orientasi proses dan prinsi fokus ada pelanggan. Perbaikan yang berkesinambungan berkaitan persis dengan komitmen atau Continuous Quality Improvemen atau CQI) dan roses (countinous process improvement. Komitmen terhadap kualitas dimulai dengan pernyataan dedikasiada misi dan visi bersama, serta pemberdayaan semua partisian untuk secara inkremental mewujudkan visi tersebut. Perbaikan yang berkesinambungan tergantung keada dua unsur. Pertama, mempelajari proses, alat, dan keteramilan yang tepat.

Kedua menerakan keteramilan baruada small achieveabl peroject. Upaya perbaikan kualitas secara terus menerus dalam suatu lembaga pendidikan harus menggunakan pendekatan system sistem terbuka atas fungsi inti lembaga pendidikan, student learning.

Ada tiga pendekatan yang digunakan sebagai bahan untuk menjamin kualitatifnya suatu lembaga pendidikan, yaitu: (1) pendekatan akreditas; (2) pendekatan outcome assesment; dan tiga tahap pendekatan sistem terbuka._ Perbaikan berkelanjutan meruakan hal penting untuk seluruh organisasi yang bermutu. Perbaikan tersebut hanya dapat dicapai bila setiap orang di berbagai sekolah atau pun wilayah bekerja bersama-sama dan : Menerapkan roda kuality mutu ada setia asepk kerja.

Memahami manfaat jangka anjang endekatan biaya mutu. Mendorong semua erbaikan baik besar mauun kecil. Memfokuskan ada upaya pencegahan dan bukan penyelesaian masalah. Pendekatan fakta ada pengambilan keputusan2 yang sangat efektif didasarkan analisis data yang benar dan informasi yang tepat. keputusan yang harus dilakukan berdasarkan pendapat atau informasi informasi lisan sering kali menimbulkan banyak penyimpangan.

Manajemen seharusnya membangun kebiasaan menggunakan data yang concrit dan hasil analisa sebelum melakukan atau menentukan pengambilan keputusan. Fakta bisa diperoleh dengan wawancara kuesioner, jejak pendapat, pengujian, analisis statistik, dan lain sebagainya yang harus memberikan hasil yang objektif. Sehingga ada tataran ini.engambilan keutusan harus didasarkan pada fakt yang nyata tentang kualitas yang didaatkan dari berbagai sumber di seluruh jajaran organisasi.

Jadi, tidak sematamata atas dasar dari intuisi, ilham, praduga, atau organizational 
politics. Berbagai alat sudah dirancang dan dikembangkan untuk mendukung engumulan dan analisi data, serta engambilan keutusan berdasarkan fakta. Hubungan yang Saling pasti Menguntungkan terhadap Pemasok Hubungan antarasekolah dan pemasoknya adalah masyarakat yang saling bergantung dan saling menguntungkan akan meningkatkan kemampuan kedua duanya untuk menciptakan nilai nilai yang bermutu.

Organisasi manajemen mutu yang sukses menjalin hubungan yang kuat dengan para pemasok dan pelanggan untuk menjamin terjadinya erbaikan mutu secara berkesinambungandalam menghasilakn barang barangd yang berjasa. Dari berbagai prinsip tersebut yang aling krusial adalah faktor kepemiminan kepala sekolah yang merupakan perannya sangat vital dalam manajerial sekolah.

Menurut wahjosumidjo, supaya fungsi kepemimpinan dari kepala sekolah yang sangat berhasil memberdayakan semua sumber daya sekolah agar bisa mencapai tinjauan sesuai dengan situasi, dibutuhkan seorang kepala sekolah yang harus memiliki kemampuan rofesioanl, yaitu: kepribadian, keahlian, dasar, pengalaman, pelatihan, dan pengetahuan profesional, dan juga kompetensi administrasi dan pengawasan._

Dengan demikian, kemampuan yang sangat profesional kepala sekolah sebagai pemimpin pendidikan yang mendidik yaitu untuk bertanggung jawab didalam menciptakan atau membuat suatu situasi KBM yang kondusif, sehingga guru2 dapat melaksanakan pembelajaran dengan sebaik baknya dan peserta didik juga dapat belajar dengan tenang dan nyaman Di samping itu juga, kepala sekolah itu selalu dituntut untuk bisa bekerja sama dengan guru atau staf yang lainnya.

Dengan demikian, pemimpinan adalah unsure unsur yang sangat penting didalam Total Quality Management. Pmimpin harus memiliki supervisi dan mampu menerjemahkan supervisi tersebut ke dalam kebijakan yang jelas dan tujuan yang sesifik. Apalagi mutu terpadu meruakan sebuah gairah dan pandangan hidu bagi organisasi yang menerapkannya. Pertanyaannya adalah bagaimana membangkitkan mutu pendidikan tersebut.

Peters dan Austin pernah melakukan peenelitian karakteristik tersebut ada dalam bukunya Passion for the Excellence. Penelitian tersebut meyakini mereka yang menentukan setiap mutu dalam suatu institusi adalah kepemimpinannya. Mereka berpendaat bahwa gaya 
kepemmimpinan tertentu bisa mengantarkan institusinya pada revolusiner mutu, sebuah gaya yang mereka singkat dengan MBWA (Management By Walkin About/ Manajamen dengan melaksanakan. Keinginan untuk selalu unggul tidak bisa dikomunikasikan ataudi bicarakan dari balik meja.

MBWA menekankan entingnya kehadiran emimin dan emahaman atau andngan mereka terhada karyawan dan roses institusi. Gaya keemiminan ini mementingkan seluruh mutu komunikasi visi dan nilai institusinya terhadap pihak-pihak yang lain, serta berbaur denagn ara staf dan pelanggan. Dalam hal ini kata mutu tidak sepenuhnya dipandang sebagai sesuatu yang melekat pada sebuah produk yang sesuai dengan kebutuhan pelanggannya, tetapi suatu produk dikatakan bermutu karena ia memiliki nilai (moh. Rifa'i).

\section{Kesimpulan}

Pelanggan yaitu semua orang yang menuntut penyedia jasa agar jasa yang dapat diterima sesuai dengan standart yang ditentukan.

Pelanggan dibedakan atas dua bagian, yaitu pelanggan dalam dan pelanggan luar. Di dalam proses prosesmengetahui harapan pelanggan yang harus dilakukan adalah dengan cara mengajukan 4 pertanyaan: yaitu (1) dengan karakteristik jasa yang selalu diinginkan pelanggan, (2) berapa tingkat kinerja kita yang dibutuhkan pelanggan, (3) Bagaimana urutan prioritas kepentingank kepentingan dari berbagai karakteristik, (4) Bagaimana kepuasan kinerja yang kita lakukan kepada pelanggan pada saat ini.

Dan apabila terjadi ketidak puasan pelanggan, kemungkinan besar terjadi tindakan dari pelanggan yaitu tidak boleh melakukan apa2, atau melakukan komplain. Adapun strategi yang harus dilakukan untuk mengembangkan kepuasan pelanggan, yang pertama yaitu relationship marketing, kedua superior customer service, ketiga unconditional guarantee, dan yang ke empat penanganan keluhan pelanggan.

\section{DAFTAR PUSTAKA}


Arbangi, Dakir, Umiarso, Manajemen Mutu Pendidikan, (Jakarta: Penerbit Kencana Prenadamedia Group, 2016).

Fandy Tjipto dan Anastasia Diana. 2009. Total quality Management. Yogyakarta: Andi.

Eti Rochaety, dkk., Sistem Informasi Manajemen Pendidikan (Jakarta: Bumi Aksara, 2006)

Wahjosumidjo, kepemimpinan kepala sekolah: tinjauan teoritik dan permasalahnnya, (Jakarta: PT RajaGrafindo Persada, 2008).

Rifa'i Moh. Community Empowermwnt in Islamic Boarding School. (Probolinggo: CV. MANDIRI). 2017. Cetakan Pertama. 